Reprod. Nutr. Dévelop., 1988, 28 (2 B), 431-441.

\title{
Responses of market lambs and Suffolk rams to a stimulatory skeleton photoperiod
}

\author{
B. D. SCHANBACHER
}

\begin{abstract}
Roman L. Hruska U.S. Meat Animal Research Center, Agricultural Research Service, U.S. Department of Agriculture, Clay Center, Nebraska 68933 U.S.A.
\end{abstract}

Summary. Young crossbred lambs and Suffolk rams were exposed to photoperiods stimulatory to growth or reproduction respectively. Whereas long days are known to facilitate rate of gain, feed efficiency and carcass yield in young market lambs, exposure to decreasing daylengths or short days is necessary for successful reproduction of the species. Successful substitution of a "skeleton" long photoperiod (7L:9D:1L: 7D) for long photoperiod (16L : 8D) exposure to growing lambs to improve performance provides strong support for the conclusion that long-day stimulation is not the result of the interval of day being illuminated but rather the time interval between two periods within a day which is illuminated. The same "skeleton " long photoperiod (7L:9D:1L:7D) is shown to substitute effectively for a long (16L : 8D) photoperiod when used alternately with a short (8L : 16D) photoperiod in eight-week light cycle exposure of mature Suffolk rams. Light cycles of this duration entrain $\mathrm{LH}$, testosterone and testicular weight and stimulate reproductive activity to a level comparable to that observed in rams during the normal breeding season. Evidence is presented that the relatively short eight-week light cycles prevent photorefractoriness from occurring and thereby can maintain indefinitely the behavioral and gametogenic activities required of the breeding ram. Implementation of short days combined with alternating « skeleton » long days should be energy efficient and may prove useful for application to sire management.

\section{Introduction.}

The effects of seasonal changes in daylength on reproduction in sheep are well known (Yeates, 1947 ; Ortavant, 1977) and numerous investigators have experimentally manipuleted reproductive activity of both ram and ewe through artificial lighting (Pelletier and Ortavant, 1975a, b; Lincoln and Peet, 1977 ; Schanbacher and Ford, 1979 ; Barrell and Lapwood, 1979 ; Bittman, Dempsey and Karsch, 1983 ; Thimonier et al., 1985). Both sexes exhibit photo-induced variations in sexual behavior and gametogenic activity with decreasing daylengths (simulated autumn) and increasing daylengths (simulated spring) producing stimulatory and inhibitory influences, respectively.

Photoperiod environment not only determines the cyclicity of reproductive activity in seasonal breeders but affects egg and milk production, body growth, 
and efficiency of feed utilization in several domestic species used for food (Tucker and Ringer, 1982). Lambs exhibit a differential growth response to contrasting long and short days with rates of gain being enhanced when lambs are exposed to 16 hours of light per day (16L: 8D) (Schanbacher and Crouse, 1980). While it is not surprising that a seasonal breeder is also photoperiodic with respect to growth, it is noteworthy that this short-day breeder grows faster and more efficiently when exposed to a long day. Initially, it was proposed that prolactin mediates the stimulatory effect of long days on lamb growth because prolactin possesses anabolic properties and blood prolactin levels are elevated during longday exposure (Schanbacher and Crouse, 1980; Forbes, 1982); however, inhibition of endogenous prolactin levels by ergot treatment or elevation of blood prolactin levels by treatment with exogenous prolactin proved ineffective at altering lamb growth and performance (Eisemann et al., 1984).

Daylength appears to be transduced by the pineal gland since the nocturnal secretion of melatonin, its principal endocrine product, most accurately reflects daylength exposure (Arendt, Symons and Laud, 1981; Lincoln et al., 1982 ; Bittman and Karsch, 1984) and timely administration of exogenous melatonin induces reproductive cyclicity comparable to that effected by exposure to alternating long and short days (Kennaway, Gilmore and Seamark, 1982). No studies have yet been conducted to ascertain whether or not melatonin mediates the stimulatory and/or inhibitory effects of daylength on lamb growth. Administration of exogenous melatonin has been restricted to reproducing stock (Lincoln, Almeida and Arendt, 1981) and most pinealectomy studies have been confined to mature individuals (Barrell and Lapwood, 1979 ; Bittman, Dempsey and Karsch, 1983). Pinealectomies have been performed in 3-month-old ram lambs in order to assess the importance of the pineal in photoperiod-induced changes in prolactin, cortisol and testosterone; a negative cortisol and testosterone response to long photoperiod was shown to require an intact pineal (Brinklow and Forbes, 1984).

Imposition of daylength effects on growth and reproduction have not been restricted to contrasting long (16L: 8D) and short (8L: 16D) days but have included a " skeleton " long photoperiod composed of eight hours of light given in two blocks, the second being a one hour block (flash) of light positioned 16 hours after the onset of the first block of light (7L : 9D : 1L: 7D). Ravault and Ortavant (1977) were able to mimic a long day and to stimulate prolactin release in Prealpes-du-Sud rams with this split photoperiod. In an experiment to study the effect of this " skeleton " long photoperiod on lamb growth, Schanbacher and Crouse (1981) exposed ram lambs to either 8L:16D, 16L:8D, or $7 \mathrm{~L}: 9 \mathrm{D}:$ $1 \mathrm{~L}:$ 7D for eleven weeks. In response to ad libitum feeding, both long-day rams and those rams exposed to the 8 hour split photoperiod had live weight gains and carcass weights significantly greater than those of short-day rams. "Skeleton " long photoperiods produced significantly lower testosterone levels than short photoperiods in rams with intact pineal glands but not in those which had been pinealectomized (Brinklow and Forbes, 1984). Pelletier and Almeida (1987) successfully substituted the 7L:9D:1L:7D split photoperiod for 16 hour daylengths in studies wherein Ile-de-France rams were exposed to light cycles of alternating short and long daylengths. When the light cycles were sufficiently 
long, exposure to short (8L: 16D) days were stimulatory while exposure to long (either 16L : 8D or 7L : 9D : 1L : 7D) days were inhibitory to $\mathrm{LH}$ and testosterone secretion and testis growth. Curiously, when the light cycles were only 8-week duration, reproductive activity persisted at a level expected of rams during the breeding season.

The intent of this review is to report on the utilization of the $7 \mathrm{~L}: 9 \mathrm{D}$ : $1 \mathrm{~L}: 7 \mathrm{D}$ " skeleton " photoperiod to stimulate weight gain in crossbred market lambs and on the suitability of this light treatment to be used in an alternating scheme with an 8-hour day $(8 \mathrm{~L}: 16 \mathrm{D})$ to maintain reproductive readiness in mature Suffolk rams.

\section{Photoperiod effects on market lambs.}

Exposure of lambs to long daylengths has been shown to result in faster weight gain than when lambs were exposed to short days (Forbes et al., 1975). Schanbacher and Crouse (1980) confirmed this observation and subsequently showed that the superior growth rate of long day lambs was paralleled by improved feed efficiency and carcass yield and that these responses were neither gonad (Schanbacher and Crouse, 1980) nor sex (Schanbacher, Hahn and Nienaber, 1982) dependent. Observations on the stimulatory effects of long days on lamb growth have been extended to preclude any interactive effects with high and low ambient temperatures (Schanbacher, Hahn and Nienaber, 1982 ; Hahn, Schanbacher and Nienaber, 1987). Not only do lambs grow more rapidly and efficiently to reach their market weights when exposed to long daylengths, but carcass weights are increased without compromise of quality or yield. These effects may, in part, be explained by the increased feed consumption by these lambs. Importantly, the beneficial effects of producing market lambs under stimulatory daylengths is not restricted to rams, wethers or ewe lambs.

Our investigations on the effects of a " skeleton " long photoperiod on lamb growth were prompted by documentation of the importance of daylength in the regulation of lamb growth and an increased awareness that daylength is measured not so much by the interval of lighting but rather by the time interval between two periods within a 24-hour day that must be illuminated (Ravault and Ortavant, 1977 ; Schanbacher et al., 1985). Table 1 shows the least-squares means for performance traits of ram lambs exposed to either a short day (8L : 16D), a long day (16L: 8D) or a "skeleton " long day (7L:9D: 1L : 7D) in which a 1 hour light pulse was given each day 16-17 $\mathrm{h}$ after dawn, i.e., dawn was subjectively defined as the beginning of the main light block. Of the three treatment groups, rams exposed to short 8 hour days gained weight the slowest and required the most feed per unit gain. Curiously, rams exposed to the split photoperiod consisting of only 8 hours of total light per day performed as well as those rams exposed to the long 16 hour day. In fact, rams exposed to the 7L : 9D : 1L : 7D and 16L : 8D photoperiods were statistically indistinguishable with regard to feed intake, feed efficiency, rate of gain, live final weight and carcass weight. The ability of a $7 \mathrm{~L}: 9 \mathrm{D}: 1 \mathrm{~L}: 7 \mathrm{D}$ photoperiod to mimic the 
TABLE 1

Least-squares means for growth and carcass data of ram lambs exposed to short (8L : 16D), long (16L: 8D) and split (7L : 9D : 1L : 7D) photoperiods.

\begin{tabular}{lcccccc}
\hline Treatment & $\begin{array}{c}\text { Avg. Daily } \\
\text { gain } \\
(\mathrm{g} / \text { day })\end{array}$ & $\begin{array}{c}\text { Feed } \\
\text { effic. } \\
(\mathrm{kg} / \mathrm{kg})\end{array}$ & $\begin{array}{c}\text { Final } \\
\text { weight } \\
(\mathrm{kg})\end{array}$ & $\begin{array}{c}\text { Carcass } \\
\text { weight } \\
(\mathrm{kg})\end{array}$ & $\begin{array}{c}\text { Quality } \\
\text { grade }\end{array}$ & $\begin{array}{c}\text { Yield } \\
\text { grade }\end{array}$ \\
\hline 8L: 16D & $345^{\mathrm{a}}$ & $4.6^{\mathrm{a}}$ & $45.4^{\mathrm{a}}$ & $21.9^{\mathrm{a}}$ & $10.7^{\mathrm{a}}$ & $3.20^{\mathrm{a}}$ \\
16L : 8D & $417^{\mathrm{b}}$ & $4.1^{\mathrm{b}}$ & $51.0^{\mathrm{b}}$ & $25.1^{\mathrm{b}}$ & $10.8^{\mathrm{a}}$ & $3.27^{\mathrm{a}}$ \\
$7 \mathrm{~L}: 9 \mathrm{D}: 1 \mathrm{~L}: 7 \mathrm{D}$ & $442^{\mathrm{b}}$ & $4.2^{\mathrm{b}}$ & $53.0^{\mathrm{b}}$ & $24.4^{\mathrm{b}}$ & $10.8^{\mathrm{a}}$ & $3.21^{\mathrm{a}}$ \\
\hline
\end{tabular}

ab Means without a common superscript differ, $(P<0.01)$.

Quality grade : $10=$ low choice, $11=$ average choice.

Yield grade : 1 = high percentage lean retail cuts, $5=$ low percentage lean retail cuts. From Schanbacher and Crouse (1981).

stimulatory effects of long days on several production traits of ram lambs has been confirmed (Schanbacher, 1982).

The existence of a photoinducible phase during the light-dark cycle must be common to biological rhythms affecting prolactin secretion, growth, reproduction and other light-sensitive processes. In sheep, this photosensitive period appears to be situated near the 16th/17th hour after dawn, since a 1 hour light pulse at the 11th, 14th and 20th $\mathrm{h}$ after subjective dawn does not elevate plasma prolactin (Ravault and Ortavant, 1977). Furthermore, the duration of the light pulse appears not to be critical since a 1-min light pulse given at the 16th hour after dawn serves equally well to stimulate prolactin release (Schanbacher et al., 1985). Light is thought to entrain circadian rhythms via the retino- and/or extraretino-hypothalamic pathways to the suprachiasmatic nucleus, thereby changing central events coupled to the light-dark cycle. While elevated prolactin may result from photostimulation of this neural circuit, prolactin itself does not appear to be causally associated with long-day stimulated growth in sheep (Eisemann et al., 1984).

\section{Photoperiod effects on Suffolk rams.}

The Suffolk ram, like rams of other nonequatorial breeds (D'Occhio, Schanbacher and Kinder, 1984), is characterized by a cyclic reproductive response to changes in daylength. These reproductive cycles have been studied in physiological detail and are presented in two informative reviews (Lincoln and Short, 1980 ; Haynes and Schanbacher, 1983). The Suffolk ram is experimentally valuable because it is the predominant sire breed used in the United States and it displays marked seasonal changes in endocrine and testicular function. In view of the U.S. sheep industry needs for fertile individuals throughout the year and the recent observation that Ile-de-France rams remain in a continuously active reproductive state when exposed to short cycles of alternating short and long 
days (Pelletier and Almeida, 1987), the reproductive response of Suffolk rams to similar light cycles has been investigated at the U.S. Meat Animal Research Center.

Twelve sexually mature Suffolk rams were randomly assigned to one of two treatment groups at the end of the fall breeding season and subsequently housed in photoperiod control chambers. Group A rams were exposed to eight-week cycles of alternating short (8L: 16D) and long (17L: 8D) photoperiods for a 60 -week study period, i.e., seven complete light cycles. Group B rams were concurrently exposed to alternating short (8L: 16D) and "skeleton " long (7L : 9D : 1L : 7D) photoperiods. Dawn was arbitrarily set at $0700 \mathrm{~h}$ for rams exposed to either 8L : 16D or 7L : 9D : 1L : 7D photoperiods, but was moved backward to $0300 \mathrm{~h}$ when group $\mathrm{A}$ rams received the 16-hour day. Testis diameter and plasma testosterone levels were monitored every four weeks at the time of daylength change. In addition, 24-hour intensive blood samplings were performed on each ram twice during the spring nonbreeding season (six months into the study and during the fourth light cycle). Plasma levels of luteinizing hormone, testosterone and melatonin were determined. Testicular and endocrine parameters were compared with those of six contemporary Suffolk rams exposed to natural daylengths.

Testis diameter of control rams continued to decline during winter and spring months with recrudescence commencing about the time of the summer solstice (Fig. 1). Mean testosterone levels for these rams were generally below $1 \mathrm{ng} / \mathrm{ml}$ during the nonbreeding season, began to increase in late spring and early summer and then returned to breeding season values (between 5 and $10 \mathrm{ng} / \mathrm{ml}$ ) the next fall. Testis diameters of rams exposed to either the $8 \mathrm{~L}: 16 \mathrm{D} / 16 \mathrm{~L}: 8 \mathrm{D}$ or $8 \mathrm{~L}$ : 16D/7L : 9D : 1L : 7D eight-week light cycles differed from those of control rams after the third month, i.e., testis size of groups $A$ and $B$ photostimulated rams increased during the nonbreeding season. As a result, testis size was maximum in

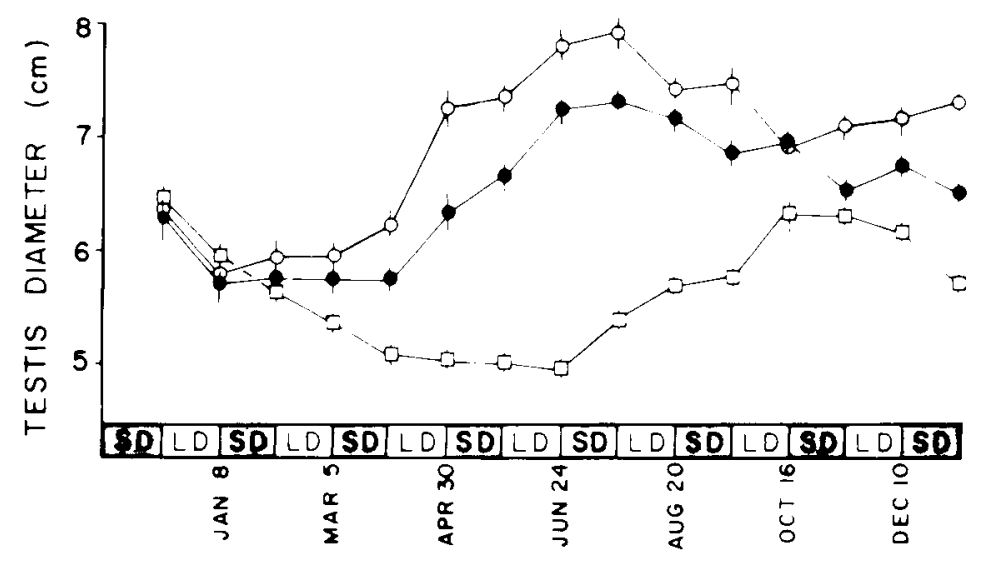

FIG. 1. - Mean testis diameter of control rams ([D), or rams exposed to either an $8 L: 16 D / 16 L: 8 D(\bullet)$ or an $8 L: 16 D / 7 L: 9 D: 1 L: 7 D(\cdots)$ eight-week light cycle. 
light-treated rams at the time of the summer solstice (Fig. 1), a finding in sharp contrast to that normally observed for rams in June. Group A and B photostimulated rams maintained large testis size into the fall breeding season and through the end of the study. Early recrudescence of the testis during the season of normal sexual quiescence and the advantage maintained by these photostimulated rams over rams exposed to the natural photoenvironment appear to be coupled to stimulation of the hypothalamo-pituitary-testicular endocrine axis. Luteinizing hormone (LH) secretion by the pituitary and testosterone secretion by the testis increased in advance of the testicular hypertrophy observed in photostimulated rams during early spring (data not shown). Associated with the elevated plasma testosterone levels was an increased sexual flush and increased incidence of Flehmen and sexual aggressiveness. Physical aggressiveness and the number of male-male confrontations was increased also.

Twenty-four hour testosterone and melatonin profiles for groups $A$ and $B$ photostimulated rams are shown in Figs $2 \mathrm{~A}$ and $\mathrm{B}$ and a summary for the secretory parameters of testosterone four weeks after exposure to either short (8L : 16D) or long (16L: 8D or $7 \mathrm{~L}: 9 \mathrm{D}: 1 \mathrm{~L}: 7 \mathrm{D})$ photoperiods during May/June are presented in Table 2. Diurnal changes in peripheral plasma melatonin were evident in all group $A$ rams with values being elevated during the dark phases 60 $100 \mathrm{pg} / \mathrm{ml}$ ) of both the $8 \mathrm{~L}: 16 \mathrm{D}$ and $16 \mathrm{~L}: 8 \mathrm{D}$ light cycles. Whereas all rams in group B produced a nocturnal rise in melatonin during the $8 \mathrm{~L}: 16 \mathrm{D}$ photoperiod cycle, only one of six rams produced a secondary rise in melatonin during the second dark phase of the 7L: 9D : 1L: 7D light cycle (i.e., after 1-hour light flash). With this exception, the 24-hour secretory patterns of melatonin in these photostimulated rams accurately reflected daylength exposure with night-time values being three- to four-fold higher than those during the day. Mean plasma testosterone values and associated secretory parameters were similar after short and long day exposure. The moderately high mean testosterone values and large testis suggest that short eight-week cycles of alternating short and long days provide a suitable photoperiod regimen to maintain Suffolk rams in a state of reproductive readiness. Furthermore, it is worthy to note that the 8 -hour split photoperiod (7L:9D:1L:7D) mimicked long-day exposure and was successfully substituted for the continuous 16 -hour day.

\section{TABLE 2}

Mean plasma testosterone levels and number and amplitude of testosterone secretory episodes in photoperiod-driven rams during the non-breeding season (May-June).

\begin{tabular}{lcrrc}
\hline & \multicolumn{2}{c}{ Group A rams } & \multicolumn{2}{c}{ Group B rams } \\
\cline { 2 - 5 } & \multicolumn{1}{c}{$(8 \mathrm{~L}: 16 \mathrm{D})$} & \multicolumn{1}{c}{$(16 \mathrm{~L}: 8 \mathrm{D})$} & $(8 \mathrm{~L}: 16 \mathrm{D})$ & $(7 \mathrm{~L}: 9 \mathrm{D}: 1 \mathrm{~L}: 7 \mathrm{D})$ \\
\hline $\mathrm{X}$ T levels/24 $\mathrm{h}$ & $5.2 \pm 0.3^{\mathrm{a}}$ & $3.6 \pm 0.4^{\mathrm{b}}$ & $4.8 \pm 0.3^{\mathrm{a}}$ & $4.2 \pm 0.4^{\mathrm{b}}$ \\
\# T peaks/24 $\mathrm{h}$ & $6.7 \pm 0.9$ & $5.2 \pm 0.8$ & $6.5 \pm 0.6$ & $6.3 \pm 1.8$ \\
X Peak Amplitude & $10.6 \pm 1.5$ & $10.4 \pm 1.1$ & $10.3 \pm 1.7$ & $10.2 \pm 1.6$ \\
\hline
\end{tabular}

Values are means $\pm \mathrm{SEM}(\mathrm{n}=6 \mathrm{rams}$ ) following four-week exposure to the prevailing photoperiod. ab Treatment means differ $(P<0.05)$. 


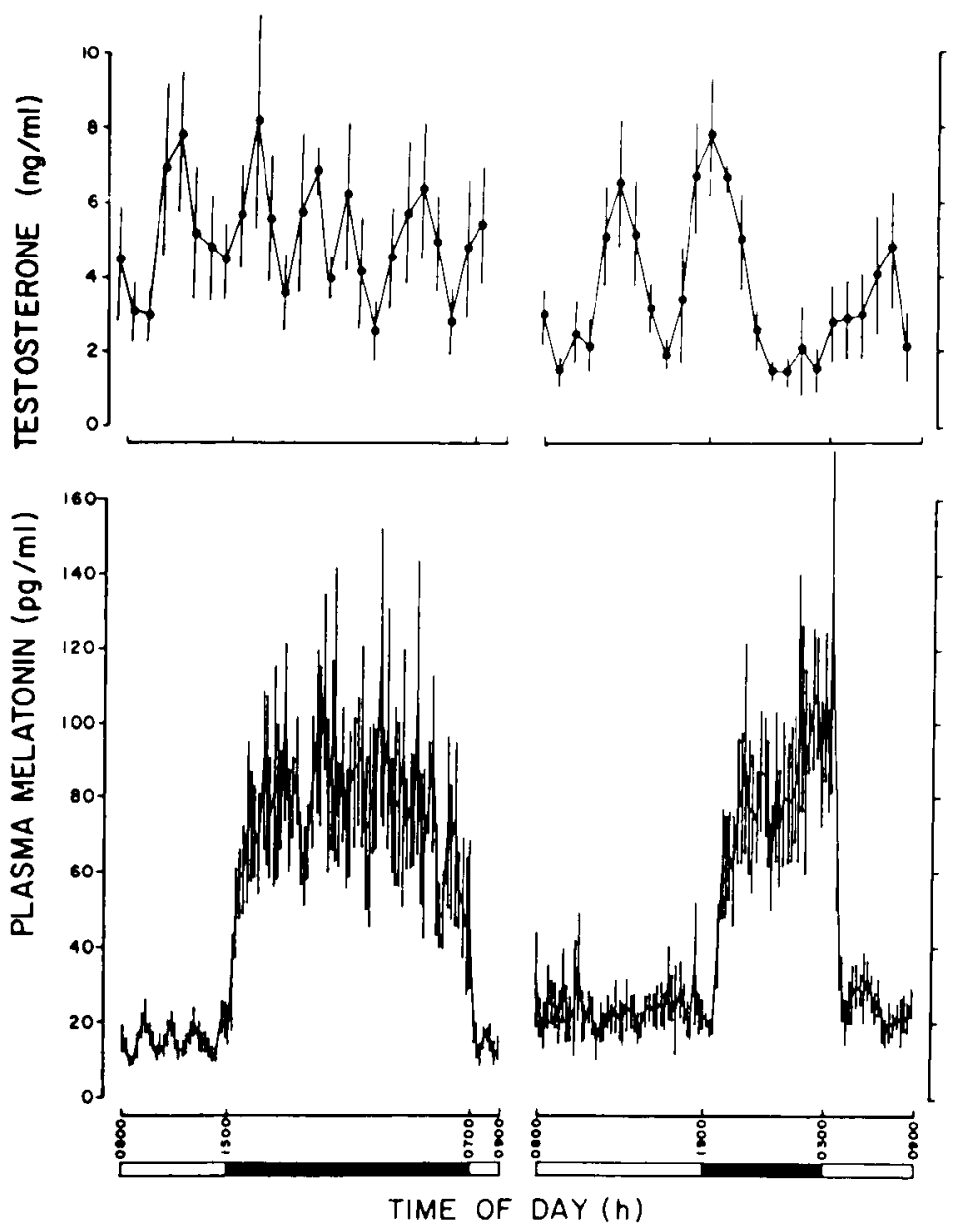

FIG. 2A. - Twenty-four hour mean profiles for plasma testosterone and melatonin in group $A$ rams exposed to an 8L : 16D/16L : 8D eight-week light cycle. The left panel shows profiles four weeks after short-day exposure while the right panel shows profiles four weeks after long-day exposure.

As discussed by Pelletier and Almeida (1987), attempts to drive the activity of the hypothalamo-hypophyseal-testicular axis by artificial light regimens have been conducted in three ways. Alternations of short and long days according to an annual cycle with a six-month phase shift results in a seasonal shift wherein artificial short days stimulate and artificial long days inhibit reproductive hormone production (Alberio, 1976 ; Sanford et al., 1978) and also stimulate or inhibit, respectively, testis weight and weekly sperm output (Ortavant and Thibault, 1956 ; Jackson and Williams, 1973 ; Colas et al., 1985). Light cycles of shorter duration (24 to 32 weeks) cause similar entrainment of LH, testosterone and testicular weight (Lincoln and Peet, 1977 ; D'Occhio, Schanbacher and Kinder, 1984 ; Pelletier and Almeida, 1987). Thirdly, experience with Ile-de-France rams 

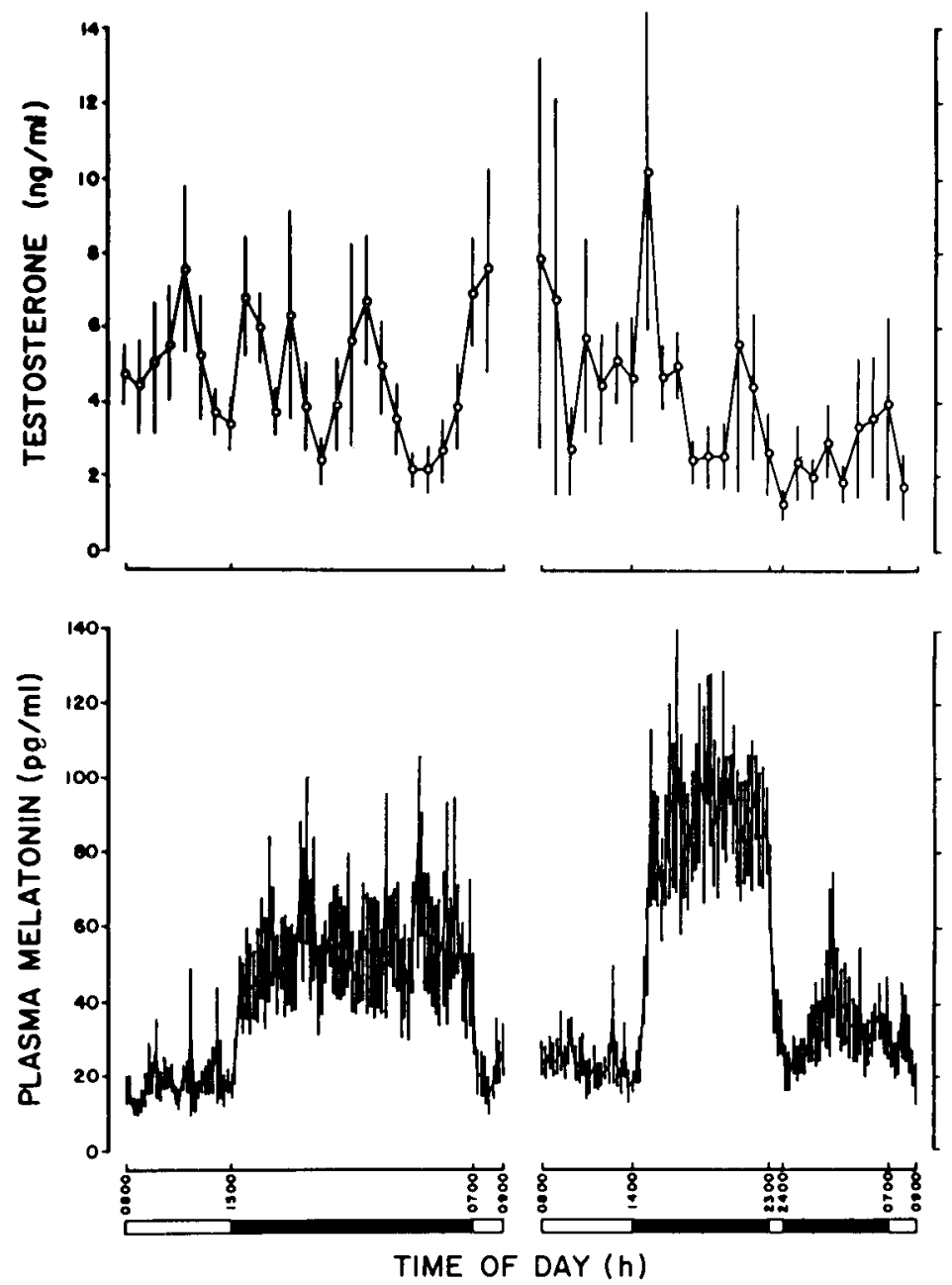

FIG. 2B. - Twenty-four hour mean profiles for plasma testosterone and melatonin in group $B$ rams exposed to an $8 L: 16 D / 7 L: 9 D: 1 L: 7 D$ eight-week light cycle. The left panel shows profiles four weeks after short-day exposure while the right panel shows profiles four weeks after "skeleton " long-day exposure.

(Pelletier and Almeida, 1987) and with Suffolk rams in the present study suggests that artificial light cycles of only eight-week duration can stimulate reproductive activity to a level comparable to that observed in rams during the normal breeding season. More importantly, both studies provide evidence that photorefractoriness is precluded when the light cycles are of short duration. Data from Suffolk rams support the postulation made by Pelletier and Almeida (1987) that testicular weight and reproductive activity are sustained by the 2-month light cycle, i.e., photorefractoriness is preempted, because $\mathrm{LH}$ and testosterone pulsatility are 
increased but apparently not at a level required for overstimulation of testosterone release and imposition of the normally coupled strong negative feedback effects of testosterone on the hypothalamo-hypophyseal complex.

Of particular interest herein is the finding that the stimulatory effects of short eight-week light cycles can consist of short 8-hour days interspersed with either long 16-hour days or the utility-efficient "skeleton " long (7L:9D: $1 \mathrm{~L}$ : 7D) photoperiod. Similarity of testis diameters and of the various hormonal characteristics measured between the two t:atment groups suggests that both the $16 \mathrm{~L}: 8 \mathrm{D}$ and the $7 \mathrm{~L}: 9 \mathrm{D}: 1 \mathrm{~L}: 7 \mathrm{D}$ photoperiods are equally effective for reproductive cycle entrainment. Indeed the stimulatory and inhibitory effects of long days are not the result of the interval of day being illuminated but rather the time interval between two periods of time within a day which are illuminated.

\section{Conclusions.}

Photosensitivity in most breeds of domestic sheep results in seasonal reproduction and metabolic adjustments which affect overall productivity of the species. Artificial lighting has been imposed to the advantage of the producer in order to produce lamb crops on a year-round basis and to enhance the young market lambs' growth rate and efficiency of feed utilization. The advantages of utilizing one of two long day regimens (i.e., 16L: 8D or $7 \mathrm{~L}: 9 \mathrm{D}: 1 \mathrm{~L}:$ 7D) for improved performance of market lambs has been summarized and the incorporation of either of these photoperiods with a short $8 \mathrm{~L}: 16 \mathrm{D}$ day in alternate four week cycles is shown to overcome seasonal regression of the testis and to stimulate testosterone secretion and those behavioral traits necessary for optimizing performance of the breeding ram. From a practical point of view, implementation of short days combined with alternating " skeleton " long days may prove energy efficient and most acceptable for management application.

Colloquium on "Neuroendocrine mechanisms and light control of reproduction in domestic mammals " I.N.R.A., Nouzilly, 17-18 September1987.

Résumé. Réponses des agneaux de boucherie et des béliers Suffolk à un régime lumineux dont la photopériode claire est fractionnée.

De jeunes agneaux croisés et des béliers Suffolk ont été exposés à des photopériodes stimulant la croissance et la reproduction. Tandis que les jours longs sont reconnus comme bénéfiques pour I'augmentation du poids, I'efficacité alimentaire et l'amélioration de la carcasse des agneaux de boucherie, l'exposition à des jours courts est nécessaire pour la reproduction. Le fractionnement de la photopériode claire (7L : 9D : 1L : 7D) entraîne les mêmes performances de croissance des agneaux que les jours longs (16L : 8D). La stimulation produite par les jours longs n'est donc pas le résultat de la durée totale d'éclairement mais plutôt, pour un jour donné, l'intervalle de temps entre deux périodes d'éclairement. Le remplacement d'une photopériode longue (16L:8D) par une photopériode fractionnée (7L:9D:1L:7D) en alternance avec des jours courts (8L: 16D), est également efficace chez le bélier Suffolk soumis à des régimes lumineux dont la période est de 8 semaines : de tels régimes entraînent la LH, la testostérone et le 
poids testiculaire et stimulent l'activité de reproduction à des niveaux comparables à ceux observés chez des béliers en saison sexuelle.

Il paraît évident que les cycles lumineux de 8 semaines empêchent l'apparition de la photoréfraction et peuvent ainsi maintenir indéfiniment le comportement de reproduction et l'activité gamétogénétique du bélier. L'utilisation d'une photopériode fractionnée de type " jours longs" en alternance avec des " jours courts", est efficace pour le contrôle de l'activité sexuelle des reproducteurs et économe en énergie.

\section{References}

ALBERIO R., 1976. Rôle de la photopériode dans le développement de la fonction de reproduction chez l'agneau /le-de-France de la naissance à 21 mois. Thèse Doct. $3^{e}$ Cycle, Univ. Paris VI, $57 \mathrm{pp}$.

ARENDT J., SYMONS A. M., LAUD C., 1981. Pineal function in sheep : evidence for a possible mechanism mediating seasonal reproductive activity. Experentia, 37, 584-589.

BARRELL G. K., LAPWOOD K. R., 1979. Effects of pinealectomy on the secretion of luteinizing hormone, testosterone and prolactin in rams exposed to various lighting regimes. $J$. Endocrinol., 80, 397-405.

BITTMAN E. L., KARSCH F. J., 1984. Nightly duration of pineal melatonin secretion determines the reproductive response to inhibitory daylength in the ewe. Biol. Reprod., 30, 585-593.

BITTMAN E. L., DEMPSEY R. J., KARSCH F. J., 1983. Pineal melatonin secretion drives the reproductive response to daylength in the ewe. Endocrinology, 113, 2276-2283.

BRINKLOW B. R., FORBES J. M., 1984. Effect of pinealectomy on the plasma concentrations of prolactin, cortisol and testosterone in sheep in short and skeleton long photoperiods. $J$. Endocrinol., 100, 287-294.

COLAS G., GUERIN Y., CLANET V., SOLARI A., 1985. Influence de la durée d'éclairement sur la production et la fécondance des spermatozoïdes chez le bélier adulte lle-de-France. Reprod. Nutr. Dévelop., 25, 101-111.

D'OCCHIO M. J., SCHANBACHER B. D., KINDER J. E., 1984. Profiles of luteinizing hormone, follicle-stimulating hormone, testosterone and prolactin in rams of diverse breeds : effects of contrasting short (8L : 16D) and long (16L : 8D) photoperiods. Biol. Reprod., 30, 1039-1054.

EISEMANN J., BAUMAN D. E., HOGUE D. E., TRAVIS H. F., 1984. Evaluation of a role for prolactin in growth and the photoperiod-induced growth response in sheep. J. anim. Sci., 59, 86-94.

FORBES J. M., 1982. Effects of lighting pattern on growth, lactation and food intake of sheep, cattle and deer. Live Prod. Sci, 9, 361-374.

FORBES J. M., DRIVER P. M., EL SHAHAT A. A., BOAZ T. G., SCANES C. G., 1975. The effect of daylength and level of feeding on serum prolactin in growing lambs. J. Endocrinol., 64, 549-554.

HAHN G. L., SChANBACHER B. D., NIENABER J. A., 1987. Performance-related responses of lambs to changes in environmental temperature and daylength. Live Prod. Sci, 16, 37-49.

HAYNES N. B., SCHANBACHER B. D., 1983. The control of reproductive activity in the ram. In : Sheep production (W. HARESIGN, ed.). Butterworths, London, pp. 431-451.

JACKSON G., WILLIAMS H. L. L., 1973. The effect of imposed light rhythms on semen production of Suffolk rams. J. agric. Sci., Camb., 81, 179-188.

KENNAWAY D. J., GILMORE T. A., SEAMARK R. F., 1982. Effect of melatonin feeding on serum prolactin and gonadotropin levels and the onset of seasonal estrous cyclicity in sheep. Endocrinology, 110, 1766-1772.

LINCOLN G. A., PEET M. J., 1977. Photoperiodic control of gonadotrophin secretion in the ram : a detailed study of the temporal changes in plasma levels of follicle-stimulating hormone, luteinizing hormone and testosterone foliowing an abrupt switch from long to short days. $J$. Endocrinol., 74, 355-367. 
LINCOLN G. A., SHORT R. V., 1980. Seasonal breeding: Nature's contraceptive. Recent Prog. Horm. Res., 36, 1-52.

LINCOLN G. A., ALMEIDA O. F. X., ARENDT J., 1981. Role of melatonin and circadian rhythms in seasonal reproduction in rams. J. Reprod. Fert., Suppl. 30, 23-30.

LINCOLN G. A., ALMEIDA O. F. X., KLANDORF H., CUNNINGHAM R. A., 1982. Hourly fluctuations in the blood levels of melatonin, prolactin, luteinizing hormone, follicle-stimulating hormone, testosterone, tri-iodothyronine, thyroxine and cortisol in rams under artificial photoperiods and the effects of cranial sympathectomy. J. Endocrinol., 92, 237-250.

ORTAVANT R., 1977. Photoperiodic regulation of reproduction in the sheep. Proc. Symp. Management of reproduction in sheep and goats, Univ. of Wisconsin, Madison, July 1977, pp. 58-71.

ORTAVANT R., THIBAULT $C$., 1956. Influence de la durée d'éclairement sur les productions spermatiques du bélier. C. R. Soc. Biol., 150, 358-362.

PELLETIER J., ORTAVANT R., 1975a. Photoperiodic control of LH release in the ram. I. Influence of increasing and decreasing light photoperiods. Acta endocrinol. Copenh., 78, 435-441.

PELLETIER J., ORTAVANT R., 1975b. Photoperiodic control of LH release in the ram. II. Light androgens interaction. Acta endocrinol. Copenh., 78, 442-450.

PELLETIER J., ALMEIDA G., 1987. Short light cycles induce persistent reproductive activity in Ile-de-France rams. J. Reprod. Fert., Suppl. 34, 215-226.

RAVAULT J. P., ORTAVANT R., 1977. Light control of prolactin secretion in sheep. Evidence for a photo-inducible phase during a diurnal rhythm. Ann. Biol. anim. Biochim. Biophys., 17, 459-473.

SANFORD L. M., BEATON D. B., HOWLAND D. E., PALMER W. M., 1978. Photoperiod induced changes in LH, FSH, prolactin and testosterone secretion in the ram. Can. J. anim. Sci., 58, $123-128$.

SCHANBACHER B. D., 1982. Responses of ram lambs to active immunization against testosterone and luteinizing hormone-releasing hormone. Am. J. Physiol., 242, E201-E205.

SCHANBACHER B. D., CROUSE J. D., 1980. Growth and performance of growing-finishing lambs exposed to long and short photoperiods. J. anim. Sci., 51, 943-948.

SCHANBACHER B. D., CROUSE J. D., 1981. Photoperiodic regulation of growth : a photosensitive phase during light-dark cycle. Am. J. Physiol., 241, E1-E5.

SCHANBACHER B. D., FORD J. J., 1979. Photoperiodic regulation of ovine spermatogenesis : relationship to serum hormones. Biol. Reprod., 20, 719-726.

SCHANBACHER B. D., HAHN G. L., NIENABER J. A., 1982. Effects of contrasting photoperiods and temperature on performance traits of confinement-reared ewe lambs. J. anim. Sci, 55 , 620-626.

SCHANBACHER B. D., WU W., NIENABER J. A., HAHN G. L., 1985. Twenty-four-hour profiles of prolactin and testosterone in ram lambs exposed to skeleton photoperiods consisting of various light pulses. J. Reprod. Fert., 73, 37-43.

THIMONIER J., BRIEU V., ORTAVANT R., PELLETIER J., 1985. Daylength measurement in sheep. Biol. Reprod., 32, Suppl. 1, 55 Abstr.

TUCKER H. A., RINGER R. K., 1982. Controlled photoperiodic environments for food animals. Science, 216, 1381-1386.

YEATES N. T. M., 1947. Influence of variation in length of day upon the breeding season of sheep. Nature, London, 160, 429-438. 